\title{
THE POWER OF
COMPASSION: THE
BUDDHIST APPROACH TO COVID-19 \\ Yu Sang
}

\begin{abstract}
A S THE CORONAVIRUS spread for mutual benefit, many people in

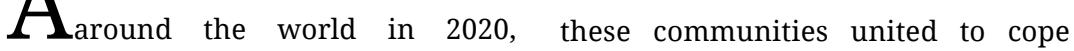
countries with significant Buddhist with the crisis, strictly obeying rules populations including Vietnam, such as mask wearing and social Cambodia, Thailand, and Myanmar distancing. Transmission was also recorded not only very low infection likely to be reduced by traditional rates, but also very few deaths. One Buddhist greetings like the Thai wai reason seems to have been the fact - pressing one's palms together in that so much of the population is front of the chest - which are more dispersed through the countryside rather than concentrated in big cities, making transmission less likely. However, some Buddhists have credited it to a faith that strongly inclines people towards caring for others and social co-operation for the common good. Working collectively hygienic than handshakes. ${ }^{1}$

In the People's Republic of China (PRC), although Buddhist temples were closed to the public as part of the society-wide lockdown, their clerics were active online, with the state's blessing or at least the approval of the Buddhist Association of China (BAC),
\end{abstract}




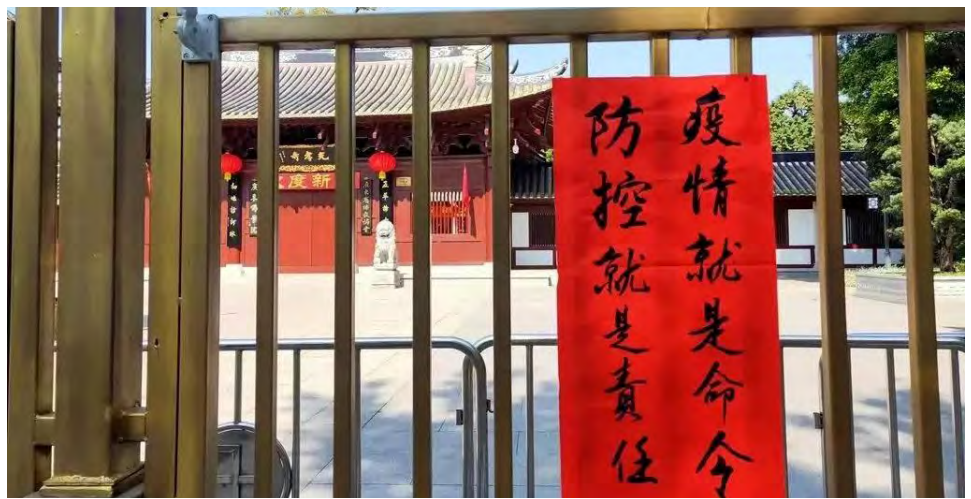

A slogan on the door of a temple in China: 'The pandemic is an order, and to prevent and control it is a responsibility' Source: Chinese National Religious Affairs Administration website

a multilevel organisation under the State Administration of Religious Affairs. The BAC issued a number of directives on how Buddhist leaders should deal with the pandemic, including donating funds to organisations such as the Chinese Red Cross and offering prayers, but also guiding believers to steer clear of superstition. ${ }^{2}$ Many local Buddhist associations (such as the Buddhist Association of Shanghai and the Buddhist Association of Tianjin) and temples (including Tianning Temple 天宁禅寺 in Changzhou, Jiangsu province, and Lingyin Temple 灵隐寺 in Hangzhou, Zhejiang province), as well as individuals (such as Master Baohan 宝菡法师 from the Temple of Great Compassion 大悲禅
院 in Tianjin), have been recognised for making significant contributions to the cause. By mid-February, the BAC and the Buddhist temples in Beijing directly under it had raised more than 5 million yuan. With the help of other Buddhist organisations like the Lingshan Charity Foundation 灵山慈善基金会, which looked after buying and distributing the goods, these funds were used to purchase masks, protective suits, ventilators, and other items needed in Hubei province, the epicentre of the epidemic in China at the time. ${ }^{3}$

On 8 August, the independent Hong Kong Buddhist Association - the territory's largest Buddhist organisation, whose charity work includes running nursing homes 
- asked all its members to pray in unison, for the pandemic in Hong Kong and elsewhere to be brought under control. ${ }^{4}$ It had also donated 50,000 masks to grassroots employees in Hong Kong, including those in schools and nursing homes, at the beginning of $2020 .^{5}$

Outside China, many Buddhist societies and individuals, such as Foo Hai Ch'an Monastery 福海 禪寺 in Singapore, the International Buddhist Temple 國際佛教觀音寺 in Canada and the Chicago Chapter of Dharma Drum Mountain 法鼓山 - an international Buddhist organisation with its headquarters in Taiwan - as well as Master Chuanyin 傳印法師 from the Seng Guan Temple 信願寺 in the Philippines, offered their support in various ways, including raising funds for medical and other charities. The power of meditation to promote health and calm anxiety emerged as a central focus of many Buddhist groups, with many temples and meditation centres providing resources such as virtual sangha (Buddhist communities of monks, nuns, and laypeople) ${ }^{6}$ and special guided online meditations for resilience and well-being. ${ }^{7}$
Two Taiwan-based Buddhist organisations were particularly active. One was the Tzu Chi 慈濟 Foundation, whose activities include international fundraising and the provision of medical aid. Not long after a bushfire relief event organised in the wake of Australia's own catastrophic start to $2020,{ }^{8}$ the Tzu Chi Foundation's Australian branch established COVID-19 Emergency Relief Assistance to help people who needed financial support but were not eligible for government assistance. ${ }^{9}$ The other was the international Fo Guang Shan 佛光山, whose activities include medical clinics and child welfare services. At the beginning of the year, the organisation's founder, Master Hsing Yun 星雲大師, offered a prayer for relief of suffering from COVID-19 and called on believers to recite the Heart Sutra 心經 together in an attempt to stop the epidemic. ${ }^{10}$ The Nan Tien Temple 南天寺 — one of Fo Guang Shan's branch temples, in Wollongong, Australia - held a prayer meeting on 1 February focused on bringing the pandemic to an early end. ${ }^{11}$

Buddhist theology emphasises the idea of 'compassion' 慈悲 or 悲 (karuṇā in Sanskrit). This is expressed 
in the Buddhist saying 'great

Dharamshala contributed money, kindness without discrimination; great compassion based on sameness in essence' 無緣大慈, 同體大悲. It is also fundamental to the spirit of a bodhisattva - a being who is motivated by 'great compassion' to achieve enlightenment and who postpones his or her enlightenment to save all other beings from suffering. ${ }^{12}$ Buddhist activities to confront the coronavirus typically cited this idea. As the pandemic spread, the Buddhist Association of Hunan Province asked all Buddhist monks in the province to cultivate a bodhisattva's spirit of compassion, feeling the pain of those who had suffered 'as if it had happened to themselves'. Buddhists across Hunan province donated money and supplies totalling 500,000 yuan in response to this call. ${ }^{13}$

In an article published on 14 April, as the global number of COVID-19 cases climbed to nearly 2 million, the Dalai Lama, Tibetan Buddhism's spiritual leader, said: 'This crisis shows us that we are not separate from one another - even when we are living apart. Therefore, we all have a responsibility to exercise compassion and help. ${ }^{14} \mathrm{He}$ and other Tibetans living in exile in protective equipment and food to pandemic relief efforts in India. Coinciding with this statement was a report that the Chinese state had used the coronavirus pandemic as a cover to further interfere in the private and devotional lives of Tibetans. While the Dalai Lama's words received global coverage, in Tibet, people were reportedly detained simply for sending prayers on social media. ${ }^{15}$ Across China, it is highly unlikely that the Dalai Lama's message made it through the online censors' 'Great Firewall'. Yet compassion was central to believers' approach to the crisis, in Tibet or elsewhere.

What do Buddhists expect to achieve with compassion in the context of a pandemic? As well as feeling sympathy for others in need and wanting to help them - core elements in the lay interpretation of compassion - Buddhist compassion evinces universal and unconditional kindness and pity, based on the idea that all living beings are the same in essence and share the same suffering. This can be traced to the Four Noble Truths (Sanskrit: catvāri ārya-satyāni), the Buddha's first and most basic teaching. ${ }^{16}$ In Buddhist philosophy, all 


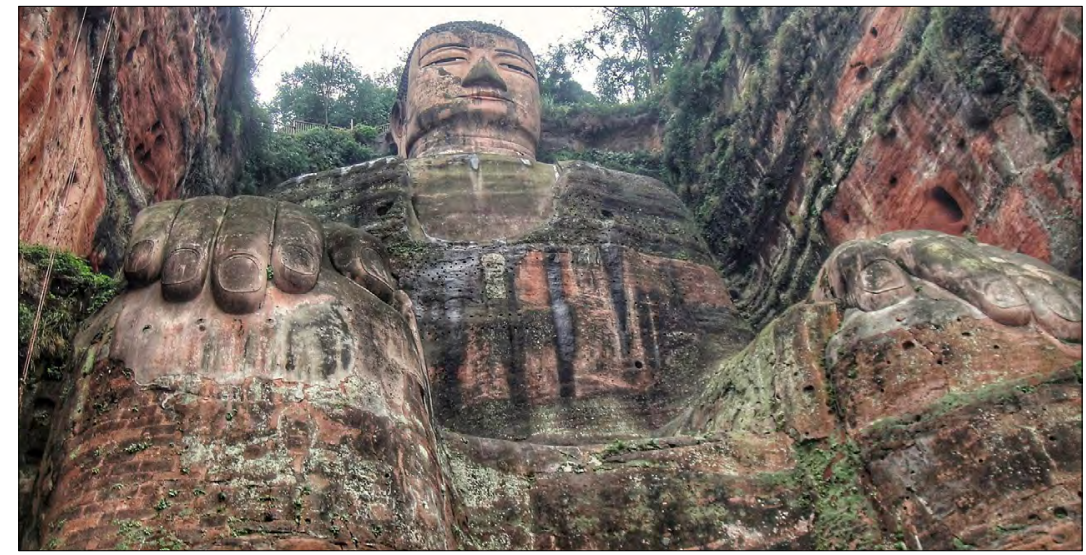

The Leshan Giant Buddha

Source: linwujin, Flickr

things in the phenomenal world are interconnected and interdependent. All sentient beings are equal and all suffer. Mental and physical suffering is due to ignorance of this and attachment to the view that things are permanent. Suffering can be eradicated by reaching enlightenment, which in turn entails compassion: the desire to free others from suffering. ${ }^{17}$ It works the other way around as well: by saving others from suffering, believers help themselves to attain enlightenment.

Two important Mahāyāna texts translated into Chinese - the Great Treatise on the Perfection of Wisdom 大智度論 (the Mahāprajñāpāramitā- śāstra) and the Treatise on the Scripture of Adorning the Great Vehicle 大乘莊嚴 經論 (the Mahāyāna-sūtrālaṃkāra) explain the meaning of 'great kindness and great compassion' 大慈大悲 as bringing happiness to all sentient beings, and liberating all sentient beings from suffering or sharing the suffering of others 大慈與一切眾生樂, 大悲拔一切眾生苦. 18

Miguel Ángel Moratinos, the High Representative for the United Nations Alliance of Civilisations, declared that the world should 'draw inspiration from Buddha's teachings' to confront the COVID-19 pandemic. We should 'show kindness and compassion to the 


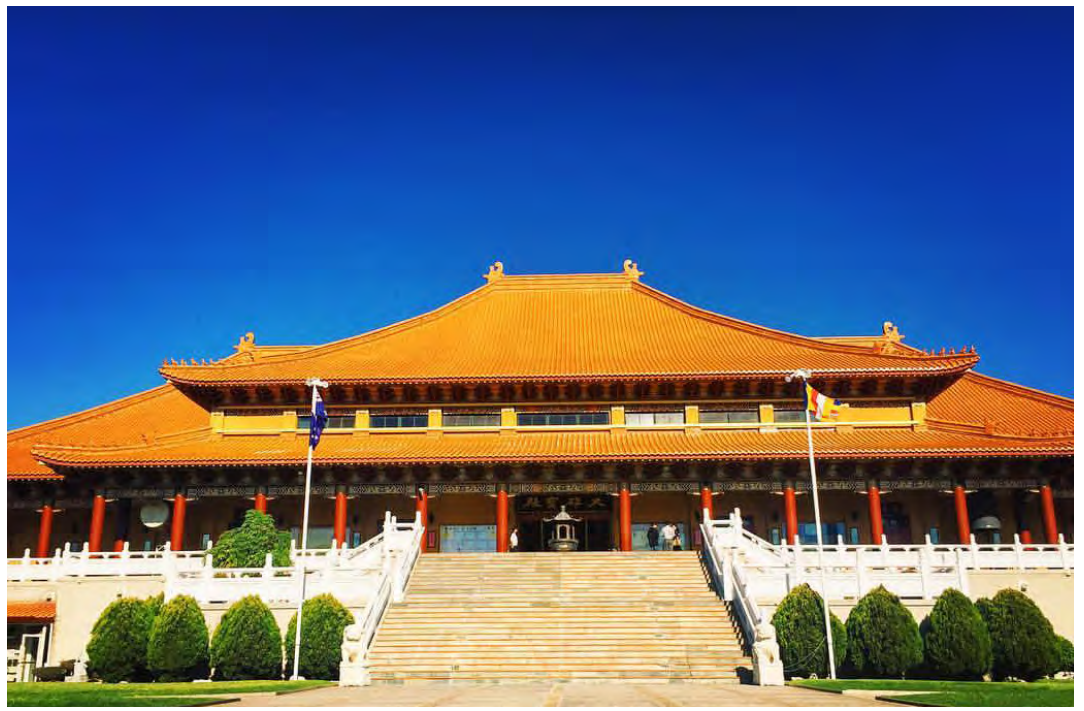

Nan Tien Temple, Wollongong

Source: Henry Ang, Flickr

most vulnerable and truly leave no one behind as we face these turbulent and difficult times together'. ${ }^{19}$

Buddhist activities such as prayer and meditation have not ended the pandemic, but the charitable and compassionate contributions made by
Buddhists the world over have been significant. They have also provided people with ways to alleviate their anxieties in confronting the COVID-19 crisis, which has been accompanied by a worrying rise in mental health problems worldwide. ${ }^{20}$ 
This text is taken from China Story Yearbook: Crisis, edited by Jane Golley and Linda Jaivin with Sharon Strange, published 2021 by ANU Press, The Australian National University, Canberra, Australia.

doi.org/10.22459/CSY.2021.04B 